member of the British Mycological Society, serving as secretary during the period 1936-42 and becoming a vice-president in 1942 .

\section{Botany at University College, Leicester}

Mr. T. G. Tutre has been appointed lecturer in charge of the Department of Botany, University College, Leicester. Mr. Tutin obtained his degree at Cambridge (Downing College) in 1930. He was demonstrator in botany at King's College, London, during 1938-39, and assistant lecturer in botany at Manchester during 1939-42. Recently, he has been working for the Admiralty. He visited British Guiana in 1933 and was a member of the Percy Sladen Trust Expedition to Lake Titicaca, Bolivia, in 1937.

\section{Military Health Services in the U.S.S.R.}

STrIKING figures in regard to the decreased deathrate among wounded Soviet soldiers were given by Dr. S. A. Sarkisov, professor of neuropathology at the Moscow Institute of the Brain, in the course of an address to the Pharmaceutical Society of Great Britain on February 8 on the health services of the Soviet Union. He said that modern warfare, involving huge armies, with its extreme mobility, its complicated tactics and strategy, and its swift wedges driven into almost completely devastated areas, has changed the whole structure of the organization of the medical service and lays entirely new demands on it, especially where first aid is concerned. Further complications are added by the use of new and powerful weapons such as mines, splinter bombs and so on. Whereas in the War of 1914-18 the majority of wounds were caused by bullets, in the present War they are due to mine and other splinters. These provoke grave wounds, extremely susceptible to infection. Despite all this, important progress in wound treatment has been made. During this War there have been only isolated cases of gas gangrene; the percentage of amputations is considerably lower than during 1914-18; the death-rate caused by bladder wounds has been reduced to a very great extent. Further improvements have resulted in a remarkable decrease of the death-rate among wounded men in the hospitals. This rate is now only 1.1 per cent, and the percentage of wounded men who have returned fit to the front is now 73 per cent. During 1914-18 it was 40 per cent. In addition, there have been no epidemics in the U.S.S.R. This is all the more significant when it is remembered that the considerable medical problems connected with the large-scale transfer of industries to the eastern parts of the country took place in the early stages of the War.

\section{The Cinematograph Film in Medical Education}

Is a leading article on the uses of the film for medical education, the Lancet (601, Nov. 4, 1944) reminds us that Dr. Braun filmed the mammalian heart in 1897 and, in that year also, Schuster, of Berlin, filmed the abnormal gait of some of his patients. The first surgical operation was filmed by the famous French surgeon, Doyan, in 1898. Yet in 1941, the Lancet directed attention to the fact that academic circles in Great Britain had then scarcely noticed "this new weapon". Those who were medical students in Manchester in the days of that great and progressive teacher of physiology, Prof. William Stirling, will remember the thrill they had when Stirling returned one day from Paris, to which he was a frequent visitor, with a film of trypanosomes in the blood. This must have been about 1906-10.

Since those days the film has become a different thing. How valuable it may be we may learn from the articles by C. J. Longland and Ronald McKeith and by B. Stanford in the Lancet (loc. cit., pp. 585 and 588). Longland and McKeith deal with the present use of the film for medical education, and the supply of films and information, giving a valuable list of organizations from which medical films can be obtained. They also discuss the use of medical films abroad, the question of how they can help medical education, plans for their use and the job of their production. Stanford gives his article to this problem of production and to the scope of the medical film. In the same issue of the Lancet (p. 615) is a note on the apparatus used in one of the laboratories of Imperial Chemical Industries, Ltd., for cinemicrography, and on another, more elaborate apparatus for high-power cinemicrography designed by R. McV. Weston (see also Nature, November 4, 1944, p. 573).

\section{The Research Defence Society}

THE annual report of the Research Defence Society, published in the Fight Against Disease (32, $2 ; 1944)$, records further progress during 1943 and a gratifying response to the appeal for funds made in 1943. This has given the Society an additional $£ 140$ a year and an addition of $£ 530$ to its invested reserve, which now stands at its highest figure in the Society's history. But its total annual receipts of about $£ 1,000$ compare sadly with the statement also made, that opponents of animal experiments have spent, during the last thirty-two years, some $£ 750,000$ of charitable money in their efforts to stop experiments requiring the use of animals. The Society hopes, nevertheless, to resume its full activities after the War, under the presidency of Lord Hailey, who succeeds the late Sir William Bragg. The annual report directs attention to the success of diphtheria immunization and to the importance of vaccination in the control of smallpox demonstrated by the recent outbreaks in London and Glasgow. The Society's publications on these and similar subjects are being used to counter systematic efforts to prejudice mothers against protection of babies against smallpox and diphtheria by sending them misleading pamphlets at hospitals and nursing homes.

The present issue of the Fight Against Disease contains, in fact, short articles on the part played by animal experiments in the study of various grave diseases, which should be valuable in countering antivivisection propaganda. 'The late Sir John Ledingham contributed a list of important advances due to, or greatly helped by, experiments on animals, among which are the prevention of diphtheria, tetanus (the menace of which has been virtually excluded from the British and American Armies during the present War), typhoid, cholera, plague, rabies and smallpox ; the diagnosis of syphilis, typhoid and paratyphoid, typhus, tuberculosis in cattle and such virus infections as influenza and yellow fever also require the use of animals; the sera for the detection of human and animal blood stains in criminal and other investigations are obtained from specially immunized animals; and animals also provide the sera used for the treatment of diphtheria, tetanus, gas gangrene, dysentery, typhus and other diseases.

Sir William Savage discusses the relation of animal experiments to the control of typhoid and other 
infectious diseases, tuberculosis, venereal disease and to other problems of public health and nutrition. Prof. J. H. Burn discusses their relation to the standardization of such therapeutic substances as insulin, neoarsphenamine and various antitoxic sera. Dr. J. W. Trevan further discusses physiological, immunological and therapeutic researches done with animals for the control of human and animal diseases, instancing diabetes, rickets, beriberi, pellagra, diphtheria, gas gangrene and, in veterinary medicine, lamb dysentery (which used to kill hundreds of thousands of new-born lambs each year) and louping ill of sheep. $\mathrm{He}$ states that tuberculosis has been virtually eliminated from cattle in the United States by the use of tuberculin for its diagnosis. We also owe the sulphonamides entirely to work done with animals, and many other drugs cannot be standardized without the use of them. Prof. George Wooldridge discusses the relief of pain and suffering in animals themselves due to experiments done on animals.

\section{Tyndall's Library}

Messrs. H. Sotheran of 2 Sackville Street, Piccadilly, W.1, have just issued an annotated catalogue of works on physics comprising the library of John Tyndall (1820-93), professor of natural philosophy at the Royal Institution, and including also other items. Of special interest are such unique items as a manuscript catalogue of the library with nearly two thousand entries, together with numerous scientific notes of Prof. Tyndall and short autobiographical details of his boyhood. Another notebook of seventy pages contains notes of his original drafts of papers and reviews with suggestions of experiments to be made. A great deal consists of personal notes, not without their humorous aspect. Of Forbes he writes, "The late Principal J. D. Forbes was a man not slow to anger. He was so sensitive as to his fame, and so eager to secure it that honest criticism was regarded by him in the light of personal attack"--typical English understatement remembering the Forbes-Rendu-Tyndall glacier controversy. Other notes connected with Ruskin and Prof. Tait include "I have heard Prof. Tait described as a rude overgrown schoolboy". The same note-book contains the first draft of his sensational presidential address at the Belfast meeting of the British Association. The catalogue of more than a thousand items includes many volumes with Tyndall's pencilled notes. Such rare works as a first edition of Huygens "Traité de la Lumière" with the full name on the title-page also appear.

\section{Industrial Safety in Spain}

A PAPER by Luis Ruiz-Castillo Basala entitled "Eliminación de accidentes en la 'Industria de la Construcción' por el conocimiento del factor humano" appears in Revista De Formacion $Y$ Documentacion Profesional (3, No. 9. Madrid, 1944), doaling with the problem of obviating accidents to those included in the category of the "Industria de la Construcción". The investigation was conducted for this class only, which includes twenty-four different forms of employment, constituting about 70 per cent of the manual workers in Spain (agricultural workers are excluded). Each of the occupations is examined separately, and the most relevant conditions which characterize them are given under the headings of physiology, psychology, hygiene and other factors.
It is believed that accidents could be eliminated to a very large extent in the branches of industry referred to by attending to certain points, among which may be noticed the following. (1) Selection of those most adaptable to the particular type of work. This could be effected by a physico-technical examination of special type, starting with a study of the characteristics enumerated for the various forms of employment. (2) Psychological influence by means of conversation, etc., on those who come under examination, to help each one to make use of his psychological qualities in the fulfilment of his daily occupation. (3) Propaganda by means of posters, handbills, and so on, having the special object of eliminating accidents. These would teach people the most convenient positions to adopt at their work and the most rational methods for proceeding with it, and would also show the necessity for remembering on all occasions the attitudes of security most fitted to avoid foreseen risks.

\section{Announcements}

THE Buchan Prize for 1945 of the Royal Meteorological Society has been awarded to Mr. E. L. Hawke, secretary of the Society.

The Secretary of State for the Colonies has made the following appointments to the Colonial Products Research Council: Mr. J. C. F. Fryer, secretary of the Agricultural Research Council, in succession to the late Dr. W. W. C. Topley ; Prof. H. V. A. Briscoe, head of the Department of Inorganic and Physical Chemistry, Imperial College of Science and Technology, in succession to the late Sir John Fox, Government chemist.

THE Council of the University of Sheffield has made the following appointments: Mr. J. H. Read, to be lecturer in chemistry; Dr. E. F. Finch, to be honorary lecturer in the history of medicine, in succession to Mr. George Wilkinson; Mr. J. Carson, to be honorary lecturer in psychology in the Faculty of Medicine, in succession to the late Dr. E. F. Skinner.

OwING to the generosity of the Rockefeller Foundation of New York, which has for a fifth year in succession provided a grant for the purpose, the Royal Society is in a position to give assistance to scientific societios and associations which, as a result of war conditions, are experiencing financial difficulties in the publication of scientific journals.

A WHOLE-DAY conference of the Nutrition Society will be held on February 24, beginning at 11 a.m., at the London School of Hygiene and Tropical Medicine, Keppel Street, W.C.1. The subject of the conference will be "Factors Affecting the Nutritive Value of Bread as Human Food". Further details of the Nutrition Society can be obtained from the Hon. Secretary, Dr. Leslie J. Harris, Nutritional Laboratory, Milton Road, Cambridge.

We have received from Messrs. Griffin and Tatlock, Kemble Street, Kingsway, London, W.C.2, particulars of some apparatus and materials, including a neat balance desiccator, polishing alumina for metallography, an anti-vibration balance table, a Kjeldahl apparatus for determining nitrogen in steel, and several other types of analytical apparatus. Publications on these may be obtained on request. 